\title{
South African Tax Incentives To Alleviate Unemployment: Lessons From United States Of America Approaches
}

Liza (ESM) Coetzee, University of Pretoria, South Africa Hanneke du Preez, University of Pretoria, South Africa Natasha K. Smale, University of Pretoria, South Africa

\begin{abstract}
A quarter of the labour force in South Africa is currently unemployed with the majority of the unemployed being unskilled youth. One of the major causes seems to be the commanding power of trades union resulting in a high minimum wage for unskilled workers, which results in a reduction in the demand for unskilled labour. To reduce the current unemployment rate in South Africa, policy decisions should be focused on youth employment with emphasis on skills development. Policy should also stimulate growth of small, medium and micro enterprises in order to stimulate job creation. A literature review indicates that current tax incentives in South Africa do not incentivise employers to hire unskilled youth labour, and are not applied on a wide enough scale to significantly impact the overall unemployment statistics. The proposed youth wage subsidy will increase the demand for unskilled labour by reducing the cost of labour. However, to have the desired impact, the participation rate must be high. The proposed subsidy was analysed against the successes and failures of subsidies implemented in the USA. It was found that many of the flaws identified in the USA have been avoided. Based on the above, the recommendation is that the proposed youth wage subsidy is plausible in a South African context and should be implemented. The main concern is that newly employed youth would replace workers who do not meet the qualifications of the subsidy. This would have to be taken into account by policy makers.
\end{abstract}

Keywords: Unemployment; Unskilled Labour; Youth; South Africa; Tax Incentives

\section{INTRODUCTION}

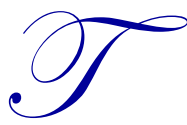

he percentage of the labour force currently unemployed in South Africa is $25 \%$. The majority of the unemployed are unskilled youth, between the ages of 18 and 29 years (Statistics South Africa, 2012:vi). The high unemployment percentage means that fewer people are contributing to the revenue pool generated by income tax. The causes of high unemployment statistics have been widely debated. One of the major causes appears to be the commanding power of trades union resulting in a high minimum wage for unskilled workers which does not correlate with their productivity. This has created an "inflexible" labour market and resulted in the reduction in the demand for unskilled labour (CDE, 2008:21).

Tax incentives to reduce the cost of labour would theoretically increase the demand for labour (Lewis, 2001:34). Although South Africa has certain indirect tax incentives, the low employment statistics prevail. Countries such as the United States of America (USA) have implemented some direct form of tax incentives over the years to motivate businesses to hire more workers. The South African Government announced in 2011 that it would spend R5 billion on job creation through a youth wage subsidy (Department of Finance, 2011:17). This could alleviate South African unemployment as it would be directly aimed at unskilled youth currently unemployed. However, the implementation thereof was halted by the Congress of South African Trade Unions (Cosatu) and the National Union of Metal Workers of South Africa (Numsa), refusing to agree to the subsidy (Anon, 2012). 
Although possible tax incentives which could be implemented in South Africa to promote job creation have been discussed (Lewis, 2001), different types of employment subsidies implemented in the USA have not been evaluated. Furthermore, the proposed youth wage subsidy has not been analysed against the successes and failures of employment subsidies implemented in the USA.

The aim of the study is to determine to what extent the causes of unemployment in South Africa have been addressed by tax legislation and whether the proposed youth wage subsidy could aid in alleviating unemployment. The proposed youth wage subsidy is also analysed against the successes and failures of tax incentives implemented in the USA.

This study provides valuable input for policy makers on whether or not the proposed youth wage subsidy is plausible in a South African context. Information available as at 26 February 2013 has been taken into account.

\section{METHODOLOGY}

Two employment incentives implemented in the USA were selected to be analysed. These two were selected because they had very different approaches and were introduced on different levels: one on a federal level (New Jobs Tax Credit) and the other in the state of Georgia (Georgia's Job Tax Credit). The USA was selected as it is considered to be the forerunner in the world. Further, although South Africa and the USA represent different contexts in respect to the extent of unemployment, the commonality is that both countries introduced incentives to alleviate unemployment. Also, the USA incentives were implemented some time ago, and there is statistical data available to analyse and compare the effect these incentives had on alleviating unemployment.

\section{THEORETICAL FOUNDATION}

\section{Unemployment in South Africa}

A government funds its state expenses by the levying of tax. High unemployment in a country means fewer people contribute to the revenue pool generated by income tax. Currently, 25\% of the South African labour force is unemployed. This is very high compared to the BRIC countries (namely Brazil 5\%, Russia 5\%, India 4\% and China $4 \%$ ) and to the USA which has an 8\% unemployment rate (Trading Economics, 2012). Furthermore, an emerging country's economy cannot grow sufficiently if $25 \%$ of its population has no income to buy goods and services to stimulate the economy. Research suggests that high and persistent unemployment can become a threat to democracy, and is associated with support for an authoritarian government (Time, 2012).

The 25\% unemployment rate in South Africa amounts to 4.3 million workers (Statistics South Africa, 2012:vi). Most of these are aged between 18 and 29 years; currently South Africa has the third highest percentage unemployed youth in the world (IndexMundi, 2012; Statistics South Africa, 2012: xiv). The level of education also plays a role; more than half of the unemployed have an education level of matric or lower (Statistics South Africa, 2012: xiv). A further worrying aspect is that South Africa performs below par when it comes to alleviating unemployment in comparison with other emerging countries such as China, Brazil and Indonesia (CDE, 2011:7).

There has been much debate and research around the causes of the South African unemployment crisis. In South Africa the trades union have the commanding power when it comes to determining minimum wages. This has caused a 'large union wage effect'- where the cost of labour is not in correlation with productivity (Lewis, 2001:13). Odendaal (2012) states that "the unskilled labour was being overpaid on average over $100 \%$ and the semi-skilled labour forces were earning close to $60 \%$ more than they should". The unskilled and semi-skilled workers are thus less attractive to employ in the labour market which has resulted in a higher level of unemployment.

This phenomenon caused South African businesses to enter into a "skills-based technological change", which has resulted in higher-skilled workers being in more demand than unskilled workers (CDE, 2008:20). This created an imbalance in the labour market in South Africa whereby most of the unemployed are unskilled. These unskilled workers are too expensive to hire. If more incentives are provided to businesses in employing unskilled labour, this could change (CDE, 2008:20). Furthermore South Africa has strict employment protection laws, which 
increases the cost of dismissal. This discourages employers from hiring for fear of incurring these costs and also results in fewer lay-offs and thus a smaller gap for the youth to occupy on entering the market (CDE, 2008:21).

In South Africa the majority of the labour market (68\%) is employed by small businesses (Adcorp, 2012:2) and therefore growth in the small business sector is crucial. Despite the Government's best efforts in providing initiatives to small businesses, South Africa is below average with regard to the number of adults starting up businesses when compared with other low- to medium income countries (SBP, 2009:2).

\section{Tax incentives within South Africa}

Although there is no direct tax relief given to an employer based on the number of workers his/her business employs, the Income Tax Act (58/1962) indirectly provides certain relief aimed at alleviating unemployment in South Africa.

Table 1: Tax relief available

\begin{tabular}{|c|c|}
\hline Section within the Income Tax Act & Causes of unemployment they could possibly resolve \\
\hline Section 12E: Small Business Corporations & Expansion of small businesses \\
\hline Section 12H: Learnership tax allowance & $\begin{array}{ll}\text { - } & \text { Reducing the cost of hiring and training employees } \\
\text { - } & \text { Skill development (all ages) }\end{array}$ \\
\hline $\begin{array}{l}\text { Section 12I: Additional investment and training in respect of } \\
\text { industrial policy projects }\end{array}$ & $\begin{array}{ll}\text { - } & \text { Creating employment opportunities } \\
\text { - } & \text { Increasing productivity } \\
\text { - } & \text { Skill development (all ages) } \\
\text { - } & \text { Expansion of small businesses }\end{array}$ \\
\hline
\end{tabular}

\section{Section 12E: Small Business Corporations}

The small and medium businesses are the driving factor in emerging economies such as South Africa's. It is within this sector that there is the capacity for businesses to grow and for the number of workers employed to increase (Lewis, 2001:25). A survey done by the World Bank indicated that it is evident that most new employment in South Africa is created by small businesses entering the market, and not by the expansion of existing businesses (Lewis, 2001:25, 31). This raises a concern for South Africa as it illustrates that existing businesses do not expand as they should.

For qualifying small business corporations, relief is provided in the form of an accelerated write-off of capital assets (100\% for manufacturing assets and 50\%/30\%/20\% per annum for other assets) and instead of the normal company tax rate of $28 \%$, a slightly more favourable sliding tax scale has been legislated. The rationale behind this is that the saving in normal tax can be used to reinvest in the business to enable it to grow.

\section{Section 12H: Learnership tax allowance}

As explained, one of the driving forces of the South African unemployment rate is the number of unskilled workers in the market and a labour market that is unwilling to employ inexperienced workers at minimum wages. This resulted in the government creating an incentive for businesses to hire and provide training through registered learnership agreements. The R30 000 allowance per employee creates an incentive for employers to hire workers for a short term, and to provide them with the necessary training to increase their employability. It also provides an incentive to ensure that the employers complete the period of the learnership agreement, by providing another tax allowance (also R30 000), once the agreement term is completed. The amount of the allowance increases to R50 000 if the learner has a disability. Furthermore, the allowance creates an opportunity for an unskilled worker to gain valuable work experience and training to increase his/her employability in the future as employers could be more willing to employ a worker who was previously employed (CDE, 2011:33).

A current evaluation of the allowance is under way, however the results are not yet available (South African Institute of Chartered Accountants, 2011). However, results of a previous evaluation published in 2007 covering the first five years of the allowance indicates that this allowance had a minimal impact at the time and that 
below $50 \%$ of the registered learners were previously unemployed (Fasset, 2007). Even though the learnership allowance was lucrative for businesses, the participation rate was low. This could be due to the stringent requirements in order to qualify for the allowance (learnerships must be registered with either a Skills Education Training Authorities (SETA) or the Manpower Training Act (56/1981)), which limited the target market to the few who qualified in terms of the requirements. Thus the allowance only resolves a small portion of the skill development problem. For the allowance to be more effective in addressing the factors of unemployment, it would have to target those who had previously been unemployed, as they are the workers' who require the work experience and skills to be more employable.

\section{Section 12I: Additional investment and training in respect of industrial policy projects}

The Department of Trade and Industry (DTI) launched this tax allowance in respect of project expenditure incurred for new projects (greenfield) or the expansion or upgrade of an existing project (brownfield). The DTI stated that the objective of the allowance was to increase the investment in manufacturing assets in order to improve the productivity of the manufacturing sector, and to train personnel in order to improve labour productivity as well as enhance the skills of the labour force (DTI, 2011:34).

Qualification for this allowance is based on a points system meeting certain criteria listed in section 12I (8)(a)-(f) of the Income Tax Act. A company has to show inter alia that it will be creating direct employment with the proposed project, and that there is evidence of training of employees for the purposes of skills development. Furthermore, the project must demonstrate that the company will be acquiring its goods and services from small, medium and micro-enterprises (SMMEs). This will ensure that smaller enterprises obtain business from this initiative, and thus aid in the growth of small businesses in the country. The further positive outcome is that a newly employed person will be provided with skills to use in the market-place elsewhere in future. analysed.

Employment subsidies will now be discussed after which the proposed youth wage subsidy will be

\section{Employment subsidies}

\section{Background}

The aim of an employment subsidy is to lower labour costs while the wage incomes of employees remain constant (Lewis, 2001:34). This could be achieved by subsidising a portion of the employer's labour costs or providing tax breaks based on the number of workers hired or jobs created (Lewis, 2001:34). It is expected that the provision of a subsidy will increase the demand for labour and these subsidies are generally aimed at less skilled workers (Lewis, 2001:34). Employment subsidies could be applied to all workers, or a specific pre-determined pool of individuals (National Treasury, 2011:28). According to Dagney (2002:263), the question that arises is whether or not these credits have created jobs that would not otherwise have been created in the absence of the credit. This type of subsidy requires more administration, which could prove to be costly. Finally, a form of 'hiring subsidy' could be implemented where the employer will get a subsidy for every worker he/she hires. This, however, could cause employers to fire and rehire individuals just to obtain the subsidy (National Treasury, 2011:28).

Burns, Edwards and Pauw (2010:2) explain that either the worker or the firm can be subsidised. The first encourages unemployed workers to actively seek employment, and the latter is an incentive for employers to employ more workers. According to Smith (2006:7), the effect of both on the labour market is identical. Burns et al. (2010:3) believe that the firm-side subsidy is more appropriate for South Africa as there is a lack of demand in the labour market. The worker-side subsidy would not be effective due to many believing that minimum wages and unionised bargaining reduced the demand for workers in South Africa.

The firm-side subsidies have certain disadvantages, which could lead to the subsidy being ineffective. If the subsidy is targeted towards a certain group of individuals, it causes a huge administrative burden on the firm as the Government will need to evaluate the eligibility of workers. This may be costly and time consuming. Dagney (2002:267) splits compliance costs into two categories, namely start-up costs (gathering information and 
implementing processes to ensure sufficient documentation) and annual costs (completing the relevant forms). For the subsidy to become successful, the benefit of the subsidy must outweigh the total additional business costs associated with it. Depending on whether the subsidy is a targeted subsidy, the firm may have concerns about assessing the eligibility of the worker based on the criteria provided. Research by Smith (2006:7-8) shows that this is a strong deterrent for firms not to act on the subsidy. Lastly, insufficient knowledge about the subsidy can also result in a low participation rate.

The employment subsidy could either be a direct payment by some or another institution or a tax credit. The latter will be easier to administer as it will form part of an already established system. According to Hungerford and Gravelle (2010:13) a tax credit may not increase the employment levels as it was designed to do. This is due to the complexity of the provisions and cost of compliance. Furthermore companies may not be aware of the credit when they make hiring decisions and demand is ultimately the determining factor in a company's hiring decisions. Some criticise employment tax incentives and state that they are only a solution when more effective means of job creation are politically indefensible (Time, 2012).

\section{Proposed employment subsidy in South Africa - Youth Wage Subsidy}

The Minister of Finance stated in his 2011 budget speech that the Government would set aside R5 billion towards youth unemployment (Department of Finance, 2011:17). The proposed youth wage subsidy as drafted by the National Treasury was submitted to the National Economic Development and Labour Council (Nedlac) for negotiation with affected parties (Parker, 2012). During this stage the policy received wide criticism and the implementation thereof was halted by the Congress of South African Trade Unions (Cosatu) and the National Union of Metal Workers of South Africa (Numsa), which refused to agree to the subsidy (Anon, 2012). The Democratic Alliance (DA) indicated that it supports the subsidy in full (Du Plessis, 2012). Cosatu's main opposition to the wage subsidy is that it will cause a substitution effect. By subsidising the youth, older workers might be replaced with young workers to ensure the subsidy is obtained (Cosatu, 2012).

The proposed subsidy is aimed at addressing the inflexible labour market and skills development. The employer is basically "compensated" for taking a risk in employing an inexperienced youth at a high wage. The duration of the subsidy is for a maximum period of two years, which the National Treasury (2011:40) believes is sufficient time to reduce the gap between wages and productivity. The employer could invest the subsidy on training and skills development. As the youth gain more work experience, the gap between the real wage and productivity will reduce (National Treasury, 2011:34), and the "employability" of the youth could increase due to work experience obtained (CDE, 2011:33).

The "guiding principle" for the subsidy was simplicity and low cost of compliance (National Treasury, 2011:39). As already explained, this will increase participation and aid in compliance. Smulders and Stiglingh (2008:335) state that among others, there is a large cost to South African small businesses in the time spent understanding the rules of the tax legislation, as well as maintaining the necessary records to comply with the rules.

The subsidy is paid to the employer by way of a rebate against either employees' tax or normal tax payable (National Treasury, 2011:43). A subsidy can be claimed for existing workers (aged between 18 and 24 years) for one year if they earn below R60 000, being the 'rounded up' tax threshold for an individual below 65 years of age for a 2011/2012 tax year. The subsidy amounts to $20 \%$ of the annual salary if the person is earning below R24 $000-$ estimated to be the maximum amount earned by the average youth in the formal sector (National Treasury, 2011:48). For workers earning R24 000, the subsidy amounts to R6 000 per annum and then gradually decreases to zero as the annual salary increases above R24 000 to R60 000, as can be seen in Table 2 below. For new workers (aged between 18 and 29 years) never employed before, the subsidy is calculated in exactly the same way except that the 20\% increases to 50\% and the subsidy for a person earning R24 000 increases to R12 000 . Again the subsidy gradually decreases to zero as the salary increases above R24 000 to R60 000, as indicated in Table 2 below (National Treasury, 2011:48). 
Table 2: Value of subsidy disaggregated into salary paid

\begin{tabular}{|c|c|c|}
\hline & Value of the subsidy & Existing workers \\
\hline Salary (Rand) & New workers & $20 \%$ of wage \\
\hline 0 & $50 \%$ of wage & 450 \\
\hline $24000-25999$ & 11370 & 4050 \\
\hline $26000-27999$ & 10740 & 3800 \\
\hline $28000-29999$ & 10110 & 3550 \\
\hline $30000-31999$ & 9480 & 3300 \\
\hline $32000-33999$ & 8850 & 3050 \\
\hline $34000-35999$ & 8220 & 2800 \\
\hline $36000-37999$ & 7590 & 2550 \\
\hline $38000-39999$ & 6960 & 2300 \\
\hline $40000-41999$ & 6330 & 2050 \\
\hline $42000-43999$ & 5700 & 1800 \\
\hline $44000-45999$ & 5070 & 1550 \\
\hline $46000-47999$ & 4440 & 1300 \\
\hline $48000-49999$ & 3810 & 1050 \\
\hline $50000-51999$ & 3180 & 800 \\
\hline $52000-53999$ & 2550 & 550 \\
\hline $54000-55999$ & 1920 & nil \\
\hline $56000-57999$ & 1290 & \\
\hline $60000-$ & Nil & \\
\hline
\end{tabular}

Source: National Treasury (2011:49)

The reason for the sliding scale is that the gap between the worker's wage and productivity will narrow as the worker gains more experience and starts earning a higher salary (National Treasury, 2011:49). The subsidy is tax exempt in the hands of the employer and therefore the employer can only claim the net wage (being the wage paid reduced by the subsidy) as a tax deduction (section 23(n) of the Income Tax Act 58/1962)).

Table 3 illustrate how much tax a company could save if it qualifies for the youth wage subsidy. Assume a company spends R24 000 a year to employ a previously unemployed worker aged 20 years and that the company had a gross income of R100 000 for the tax year. Without the youth wage subsidy, the company would be paying R21 280 in income tax. Conversely, if the subsidy could be claimed, the company would only be liable for R12 640 in income tax using the subsidy values set out above. The subsidy reduces the employer's effective cost of youth labour by $36 \%$ being R8 640 divided by R24 000 .

Table 3: Tax savings if company employed a new worker at a salary of R24 000 a year

\begin{tabular}{|l|c|c|}
\hline \multirow{2}{*}{} & \multicolumn{2}{|c|}{ Normal tax liability (Rand) } \\
\cline { 2 - 3 } & With the subsidy & Without the subsidy \\
\hline Gross income & 100000 & Nil \\
\hline Grant received - exempt in employer's hands & Nil & -24000 \\
\hline Salary deduction (net of subsidy to be received) & -12000 & $\mathbf{7 6 0 0 0}$ \\
\hline Taxable income & $\mathbf{8 8 0 0 0}$ & 21280 \\
\hline & & Nil \\
\hline Normal tax liability (28\%) & 24640 & $\mathbf{2 1 2 8 0}$ \\
\hline Tax credit & -12000 & $\mathbf{2 2 ~ 6 4 0}$ \\
\hline Net tax liability & & $\mathbf{8 6 4 0}$ \\
\hline
\end{tabular}
being R46 000.

In Table 4 the tax saving is illustrated for the same example, except that the salary is greater than R24 000 , 
Table 4: Tax savings if company employed a new worker at a salary of R46 000 a year

\begin{tabular}{|l|c|c|}
\hline \multirow{2}{*}{} & \multicolumn{2}{|c|}{ Normal tax liability (Rand) } \\
\cline { 2 - 3 } & With the subsidy & Without the subsidy \\
\hline Gross income & 100000 & Nil \\
\hline Grant received - exempt in employer's hands & Nil & -46000 \\
\hline Salary deduction (net of subsidy to be received) & -41560 & $\mathbf{5 4 0 0 0}$ \\
\hline Taxable income & $\mathbf{5 8 4 4 0}$ & 15120 \\
\hline & & Nil \\
\hline Normal tax liability (28\%) & 16363 & $\mathbf{1 5 1 2 0}$ \\
\hline Tax credit & -4440 & $\mathbf{1 1 9 2 3}$ \\
\hline Net tax liability & & $\mathbf{2}$ \\
\hline
\end{tabular}

Note that the subsidy reduces as the salary increases. Using Table 2, the company would qualify for a credit of R4 440. The tax saving is now only R3 197 and the cost of labour is reduced by approximately 7\% (being R3 197 divided by R48 000). The benefit at this salary level is marginal and it is evident that the aim of the subsidy is to motivate the employers to hire "lower-skilled, lower wage" workers (National Treasury, 2011:48). This is because the National Treasury wishes to target the majority of the unemployed youth, which they deem to be earning within the R24 000 a year range.

The wage elasticity of the labour demand will determine how much of an impact the difference in the cost of labour will have on the labour demand. South Africa's national average for wage elasticity is typically in the region of -0.5 to -0.7 (Development Policy Research Unit, 2008:10). However, Fedderke (in National Treasury, 2011:51) states that the wage elasticity of unskilled workers is between -2 and -2.23 , which is an indication that unskilled labour is highly sensitive to wage changes. Thus, the benefit of targeting the unskilled youth is that the change in the cost of labour will theoretically have a significant impact on the demand for unskilled youth. Assuming a 36\% decrease in labour costs, the minimum impact of the wage changes (assuming the national average elasticity of -0.5 ) is an $18 \%$ decrease in the youth unemployment rate. If the unskilled workers' elasticity of -2 is applied, the minimum decrease of youth unemployment would be $72 \%$. The subsidy is expected to increase the number of jobs by 423000 throughout its duration of which only $178000(42 \%)$ would have been created in the absence of the subsidy. Therefore, $58 \%$ of the 423000 jobs will be created as a result of the subsidy (National Treasury, 2011:40).

\section{Employment subsidies implemented in the United States of America}

\section{Federal government level - New Jobs Tax Credit}

The New Jobs tax credit (NJTC) granted employers a tax credit in respect of the incremental jobs created. Employers qualified if they increased wages paid to at least $102 \%$ of the previous year's wage base and if the wage bill had grown by $5 \%$ from the previous year. The credit was $50 \%$ of the increase in the wage base, but various limitations reduced the maximum benefit per employee further. A ceiling was also placed on the credit that a company could claim in total. It was therefore more beneficial for smaller to medium sized companies with fewer employees to apply for the credit than larger corporations (United States Department of Labor and Treasury, 1986:30-31; Time, 2012). Over the course of its brief expensive life, the NJTC probably created only a handful of jobs (Time, 2012). It was probably the complexity of the programme which could have increased compliance costs that resulted in some companies opting not to participate.

\section{$\underline{\text { State level - Georgia Job Tax Credit }}$}

The Georgia Job Tax Credit had a different approach. The state provided a credit per full-time job created. It was a targeted subsidy, in that certain counties within Georgia in need of more development were identified. Those counties were assigned a higher credit per job created as well as a higher minimum of jobs to be created. The minimum number of jobs did not have to be maintained. However, if a company maintained its minimum number of jobs, it was entitled to claim the credit for each year in which it had maintained the minimum. The company could 
only reduce its tax liability by a maximum of $50 \%$ by utilising the credit and could therefore not create a tax loss. Any unused credits could be carried forward to the next tax year (Dagney, 2002:265-266).

The companies that participated in the Georgia Job Tax Credit increased their employment by over 50\% (2002:271). Furthermore, the change in employment was greater in larger companies as these companies were more likely to have the capacity to take on more workers without a significant impact on their bottom line. Nonparticipating companies either were not aware of the credit, or the cost of participating was greater than the credit that they would have received (Dagney's, 2002:273). The Georgia employment subsidy therefore yielded positive benefits.

Although participating firms created between $24 \%$ and $28 \%$ more jobs (1 870 and 2196 jobs), $72 \%$ to $77 \%$ of those jobs created would have been created in the absence of the credit (Dagney, 2002:277). The credit therefore did not significantly influence employment decisions, but still aided in reducing the cost of labour.

\section{FINDINGS}

To reduce the current unemployment rate in South Africa, policy decisions should be focused on youth employment with emphasis on skills development. Policy makers will also need to focus on what SMMEs identify as their constraints to growth, as growth in this sector will lead to higher employment.

It is clear that the three types of indirect relief provided by tax legislation do not adequately address the causes of unemployment, as they are not directly focused on incentivising employers to hire unskilled youth labour. Furthermore, they are not on a wide enough scale to make a significant impact on the overall unemployment rate in South Africa.

The small business corporation tax does not directly incentivise employment and there is also no guarantee that these businesses will use an amount equal to the amount of tax saved to employ more workers. Although the learnership allowance deals with the concern of skills shortage in South Africa, it does not focus on previously unemployed individuals. Currently an evaluation of the allowance is under way, but there is currently no evidence available to prove that a learner is able to find employment after completing a learnership. The allowance in respect of additional investment and training in industrial projects could be an answer to creating sustainable employment for the labour force of South Africa. However, the process to obtain approval for the project seems long and onerous and the administrative burden placed on a company may outweigh the benefit. Furthermore, the allowance is aimed more at businesses that are able to fund large expansion projects. Except for the points allocated to purchasing goods, this allowance is not focused on promoting SMMEs.

Based on the above research it is evident that there is a need for a more direct incentive aimed at the majority of the unemployed in South Africa, which is exactly what the proposed youth wage subsidy would do. It follows a similar pattern to that of the Georgia Tax Credit in that it is targeted at a specific group of individuals, namely the unskilled low income youth. Furthermore, although the subsidy is not specifically targeted at SMMEs, it would be lucrative for these businesses to participate due to low administration costs and the simplified design of the policy. However, the participation rate will have to be high to make a significant impact on the unemployment rates.

The proposed design avoids many of the flaws identified in the USA. The Georgia Tax Credit was simple and accessible, which increased its success rate. In comparison, the NJTC was overly complex which caused high compliance costs, which resulted in its low participation rate limiting its impact. Although the youth wage subsidy was designed to have a low cost of compliance, finding suitable unemployed youths might result in additional costs to the employer. This could be overcome by way of job assistance programmes in order to reduce the time and money spent by businesses searching for youths to employ.

Any ceiling imposed by policy makers is also a determining factor in the participation rate. The Georgia Tax Credit had ceilings, namely a minimum number of jobs had to be created and a company could not reduce its tax liability by more than $50 \%$ in utilising the credit. The youth wage subsidy has no such ceilings which makes the youth wage subsidy more lucrative. The administration burden created by the Georgia Tax Credit to prove the 
number of workers employed will be eliminated and the employer can use the full tax credit in any given year. This will mean that each job created will result in a tax benefit which is expected to increase the participation rate.

Another benefit that companies would have under the proposed youth wage subsidy is that the employer has the option to claim the subsidy either through the PAYE system or through a tax credit on the company's annual income tax return. This places the power of choice into the taxpayer's hands, which increases the motivation to participate. The subsidy is also designed in such a way that the company will reduce the amount owed to SARS instead of physically applying for the subsidy, which provides more motivation to businesses to participate as the benefits will be more immediate.

To combat a possible substitution effect, the design of the subsidy should ensure that the rights of workers not eligible for the subsidy are protected. The policy could, for example state that the employment level of older workers before the implementation should be maintained after implementation. This will then have to be confirmed by way of audits by either SARS or the Department of Labour.

The one unavoidable consequence of the subsidies in the USA was that jobs were subsidised which would have ordinarily been created in the absence of the subsidy. Unfortunately this might also happen in the case of the youth subsidy.

In theory, the youth wage subsidy would influence the majority of the unemployed in the South African labour market. It cannot guarantee that the unskilled youth will obtain the skills needed to be able to be more employable in future. However, it would demonstrate that the youth are employable and it is hoped that the two years' experience gained by the subsidy would increase their employability.

\section{CONCLUSION}

The aim of this study is to provide valuable input for policy makers on whether or not the proposed youth wage subsidy is a plausible solution to unemployment in the South African context. To reduce the current unemployment rate in South Africa, policy decisions should be focused on youth employment with emphasis on skill development. It should also stimulate growth of SMMEs and job creation.

A literature review indicates that current tax incentives in South Africa do not incentivise employers to hire unskilled youth labour and are not on a wide enough scale to significantly impact on the overall unemployment statistics. The proposed youth wage subsidy will not only increase the demand for unskilled labour, but will also reduce the cost of labour, which is crucial in an "inflexible" labour market. However, to have the desired impact, the participation rate must be high.

The proposed youth wage subsidy was analysed against the successes and failures of subsidies implemented in the USA. It was found that many of the flaws identified in the USA have been avoided, such as subsidies being overly complex and a large administrative burden to the employer. The proposed youth wage subsidy is simple and accessible with low compliance costs. No ceilings are proposed which will mean that each job created will result in a tax benefit. The employer has the option to use the full credit either through the PAYE system or as a tax credit on the annual income tax return. This will make the benefit more immediate as opposed to applying for a subsidy and will improve the employer's cash flow.

Based on the above, it is noted that that the proposed youth wage subsidy is plausible in a South African context and it is recommended that the subsidy should be implemented. The main concern is that newly employed youth would replace workers who do not meet the qualifications of the subsidy. This would defeat the purpose of creating employment and would have to be taken into account by policy makers. The one unavoidable consequence of the youth wage subsidy might be that jobs will be subsidised that would ordinarily have been created in the absence of the subsidy. Furthermore, the subsidy is not a guarantee that the unskilled youth will obtain the skills needed to be able to be more employable in future. 


\section{AUTHORS' INFORMATION}

Mrs Liza (ESM) Coetzee, B.Com (Accountancy) (cum laude); B.Com (Accountancy) (Honours), H Dip (Tax Law); M.Com (Taxation) (cum laude), University of Pretoria, The South African Institute of Chartered Accountants (SAICA), The South African Institute of Tax Practitioners (SAIT). Liza Coetzee is a consulting chartered accountant and a senior lecturer at the University of Pretoria, South Africa. She lectures taxation on a postgraduate level and acts as a research supervisor on a postgraduate level. Her research interests centres on socio-economic issues such as the tax deductibility of expense incurred by parents caring for their disabled children and changing employment relations. She is a mother of four. Mrs Liza Coetzee, Department of Taxation, Main campus EMS Building 4-14, University of Pretoria, Private Bag X20, Hatfield, South Africa, 0028. E-mail: liza.coetzee@up.ac.za (Corresponding author)

Mrs Hanneke du Preez, BA (HED); B Compt (honours); Postgraduate certificate in advanced taxation; M Com (Taxation)(cum laude), University of Pretoria, The South African Institute of Chartered Accountants (SAICA), The South African Institute of Tax Practitioners (SAIT). Hanneke du Preez is a consulting chartered accountant and senior lecturer at the University of Pretoria, South Africa. She lectures taxation on an undergraduate level and does research supervision on a postgraduate level. She has been involved in education, first as a secondary school teacher specialising in Accounting and Geography studies, and currently as senior lecturer in taxation. Her research interests centres on the teaching practices of taxation students and the assessment practices of professional board examinations, specifically related to open-book assessment. Mrs Hanneke du Preez, Department of Taxation, Main campus EMS Building 4-3, University of Pretoria, Private Bag X20, Hatfield, South Africa, 0028. E-mail: hanneke.dupreez@up.ac.za

Miss Natasha K. Smale, B.Com (Accountancy) (cum laude); B.Com (Accountancy) (Honours), M.Com (Taxation) (cum laude), University of Pretoria. Natasha's research interests centres on socio-economic issues such as unemployment. Miss N. K. Smale, Department of Taxation, Main campus EMS Building 4-11, University of Pretoria, Private Bag X20, Hatfield, South Africa, 0028.

\section{REFERENCES}

1. Adcorp. 2012. Adcorp employment index, February 2012. [Online] Available from: http://www.adcorp.co.za/NEws/Pages/Newbusinessstart-upsslumptoall-timelow.aspx [Downloaded: 201204-25].

2. Anon. 2012. Cosatu and Numsa on the youth wage subsidy. Numsa News, 2 July. [Online] Available from: http://numsa.org.za/article/cosatu-and-numsa-on-the-youth-wage-subsidy-2012-08-16 [Accessed: 2012-0915].

3. Burns, J., Edwards, L. \& Pauw, K. 2010. Wage subsidies to combat unemployment and poverty: assessing South Africa's options. [Online] Available from:

http://www.saldru.uct.ac.za/home/index.php?/component/option,com docman/Itemid,32/gid,360/task,doc view/ [Downloaded: 2012-08-28].

4. CDE: Centre for Development and Enterprise. 2008. South Africa's 'door knockers': young people and unemployment in metropolitan South Africa. [Online] Available from: http://www.cde.org.za/article.php?a id=313 [Downloaded: 17-04-2012].

5. CDE: Centre for Development and Enterprise. 2011. A fresh look at unemployment. [Online] Available from: http://www.cde.org.za/article.php?a_id=400 [Downloaded: 2012-04-17].

6. Cosatu: Congress of South African Trade Unions. 2012. Why a youth wage subsidy won't work. Politicsweb, 25 June. [Online] Available from: http://www.politicsweb.co.za/politicsweb/view/politi csweb/en/page71619?oid=308054\&sn=Detail\&pid=71619 [Accessed: $2012-08-28$ ].

7. Dagney, F. 2002. Do state economic development incentives create jobs? An analysis of state employment tax credits. National Tax Journal, 2(55):263-280. [Online] Available from: http://ntj.tax.org/wwtax/ntjrec.nsf/175d710dffc186a385256a31007cb40f/7f9c2b03333848dc85256c6f0061 016c? OpenDocument [Downloaded: 2012-08-28]. 
8. Development Policy Research Unit. 2008. Minimum wages, employment and household poverty: investigating the impact of sectoral determinations. [Online] Available from:

https://www.labur.gov.za/downloads/documents/researchdocuments/Sectoral\%20determinations\%20POLICY\%20VERSION\%20v4.pdf [Downloaded: 2012-09-14].

9. TI: Department of Trade and Industry. 2011. A guide to the DTI Incentive schemes 2011/12. [Online] Available from: http://www.ecdc.co.za/files/documents/tenderdocs/the\%20dti\%20Incentive\%20Schemes\% 20Booklet.pdf [Downloaded: 2012-04-17].

10. Du Plessis, C. 2012. D-day for youth wage subsidy. City Press, 15 August. [Online] Available from: http://www.citypress.co.za/Politics/News/D-Day-for-youth-wage-subsidy-debate-20120815 [Accessed: 2012-09-03].

11. Fasset. 2007. Fasset learnership statistics. [Online] Available from: http://www.fasset.org.za/learnerships/default.asp?thepage=statistics.htm [Accessed: 2012-05-04].

12. Hungergord, T.L. \& Gravelle, J.G. 2010. Business investment and employment tax incentives to stimulate the economy. [Online] Available from: http://assets.opencrs.com/rpts/R41034_20100122.pdf [Downloaded: 2012-08-28].

13. IndexMundi. 2012. Unemployment, youth ages 15-24. [Online] Available from: http://www.indexmundi.com/g/r.aspx? $\mathrm{v}=2229$ [Accessed: 2012-04-25].

14. Lewis, J.D. World Bank. 2001. World Bank discussion paper: policies to promote growth and employment in South Africa. [Online] Available from:

http://www.tips.org.za/files/Policies to Promote Growth and Employment in South_Africa.pdf [Downloaded: 2011-10-10].

15. Parker, F. 2012. DA calls on Zuma to back youth wage subsidy. Mail \& Guardian, 10 September. [Online] Available from: http://mg.co.za/article/2012-09-10-da-calls-on-zuma-to-back-the-youth-wage-subsidy [Accessed: 2012-09-15].

16. SBP. 2009. Small business development in South Africa: time to re-assess. [Online] Available from: [Downloaded: 2011-10-10].

17. Smith, C. 2006. International experience with worker-side and employer-side wage and employment subsidies, and job assistance programmes: implications for South Africa. [Online] Available from: http://www.hsrc.ac.za/Research_Publication-19585.phtml [Downloaded: 2012-08-28].

18. Smulders, S. \& Stiglingh, M. 2008. Annual tax compliance costs for small businesses: a survey of tax practitioners. South African Journal of Economic and Management Sciences, 11(3):354-371.

19. South Africa. 1962. Income Tax Act, No. 58 of 1962. Government Gazette. [Online] Available from: http://www.acts.co.za/tax/index.htm [Accessed: 2012-05-25].

20. South Africa. Department of Finance. 2011. 2011 Budget speech. [Online] Available from: http://www.sars.gov.za/home.asp?pid=66066 [Downloaded: 2011-10-12].

21. South Africa. National Treasury. 2011. Confronting youth unemployment: policy options for South Africa. [Online] Available from:

http://www.treasury.gov.za/documents/national\%20budget/2011/Confronting\%20youth\%20unemployment \%20-\%20Policy\%20options.pdf [Downloaded: 10-10-2011].

22. South African Institute of Chartered Accountants. 2011. SAICA welcomes proposal to extend learnership tax allowance. [Online] Available from:

https://www.saica.co.za/News/NewsArticlesandPressmediareleases/tabid/695/itemid/2846/language/enUS/Default.aspx [Accessed: 2012-05-05].

23. Statistics South Africa. 2012. Quarterly Labour Force Survey - Quarter 1, 2012. Statistical Release P0211. 28 July. [Online] Available from: http://www.statssa.gov.za/publications/P0211/P02111stQuarter2012.pdf [Downloaded: 2012-05-13].

24. TIME. 2012. Obama's Job Creation Tax Credit: Cool idea, Bad policy. 24 February. [Online] Available from: http://business.time.com/2012/02/24/obamas-job-creation-tax-credit-cool-idea-bad-policy/ [Downloaded: 2013-01-24].

25. Trading Economics. 2012. Unemployment-rates [Online] Available from: http://www.tradingeconomics.com/country-liist/unemployment-rate [Accessed: 2013-01-22].

26. United States Department of Labor and Treasury. 1986. The use of tax subsidies for employment: a report to Congress by the Department of Labor and Treasury. [Online] Available from: http://archive.org/details/useoftaxsubsidie01unit [Downloaded: 2012-05-25]. 
NOTES 